\title{
Role of small-scale independent providers in water and sanitation
}

\author{
Meine Pieter van Dijk \\ UNESCO-IHE Institute for Water Education, \\ PO Box 3015, 2601 DA Delft, \\ The Netherlands \\ E-mail: m.vandijk@unesco-ihe.org
}

\begin{abstract}
Small-scale independent providers (SSIPs) and households are good for $10-69 \%$ of the household water supply and sometimes up to $95 \%$ of the sanitation solutions in cities in developing countries. Different types of SSIP can be distinguished. They could be allowed to make a more important contribution to drinking water and sanitation in a situation where many governments cannot be the only one to supply drinking water and sanitary services. Theoretical and practical arguments are used to explain why private sector involvement is even more frequent in sanitation than in drinking water. The issue of how to improve the efficiency in the water and sanitation sector will be raised by looking at ways to unbundle sanitation, to use technological innovations and to bring in more competition. The need for alternative technologies is stressed, since a fully fledged sewerage system in every Third World city would contribute to increased foreign debt in many countries, given that the steel and cement often need to be imported.
\end{abstract}

Keywords: sanitation; unbundling; Private Sector Involvement; PSI; technological developments.

Reference to this paper should be made as follows: van Dijk M.P. (2008), 'The role of small-scale independent providers in water and sanitation', Int. J. Water, Vol. 4, No. 3/4, pp.275-289.

Biographical notes: Meine Pieter van Dijk is an Economist and Professor of Water Services Management at UNESCO-IHE Institute for Water Education in Delft and a Professor of Urban Management at the Institute of Social Studies in The Hague, both in The Netherlands. He received his $\mathrm{PhD}$ in Economics from Free University Amsterdam.He is a member of the research schools CERES and SENSE. His recent books are Managing Cities in Developing Countries, the Theory and Practice of Urban Management (2006, Cheltenham: Edgar Elgar) and with C. Sijbesma (eds, 2006) Water and Sanitation Institutional Challenges in India (New Delhi: Manohar).

\section{Introduction}

It is often noted that drinking water issues receive much more attention than sanitation issues. The proof that sanitation is very much neglected is the simple figure that the number of people with no access to toilet facilities is more than twice the number of people having no access to safe water. ${ }^{1}$ Several reasons can be mentioned why not enough attention is paid to sanitation. In the first place most people consider drinking water a 
priority, but do not always see the need for proper sanitation. Similarly, people are willing to pay for drinking water, but are much more reluctant to invest in proper sanitation. It must be noted that connection fees for sanitation also tend to be higher than for drinking water, if only because it is more difficult to recover the investments later, which is certainly possible in the case of drinking water. ${ }^{2}$ In the third place drinking water supply unlike sanitation is more often characterised as a natural monopoly and hence considered the responsibility of the government. ${ }^{3}$

It will be argued on theoretical and practical grounds that there is even less of a natural monopoly in the sanitation sector than in drinking water. Hence in many developing countries more can be left to private solutions, often involving the small-scale local private sector. In practice the solution of the sanitation problems is often already left to individual households, instead of expecting the solution to be supplied by the government (WSP, 2004). This is partly because many countries have adopted a strategy of decentralisation and devolution for water supply and sanitation. They put the responsibility for sanitation at the municipal level, but without providing the necessary means to lower levels of government for this purpose. This means not much is happening since we know that the investments in the construction, or rehabilitation of new water and sanitation systems is many times what is required to extend or upgrade an existing system.

First, sanitation will be defined and the role for the private sector in sanitation will be assessed. Subsequently, data on the importance of Small-Scale Independent Providers (SSIPs) in the drinking water and sanitation sector will be reviewed. Then, the issue how to improve efficiency in sanitation will be raised by looking at the possibility to unbundle this activity, to use technological innovations and to bring in more competition. Finally, some dilemmas will be discussed related to the Millennium Development Goals (MDGs) and the role of the private sector in sanitation.

\section{Sanitation, a definition and the role of private sector}

Sanitation is defined as safe collection, storage, treatment and disposing in a hygienic way of waste, including human excreta (faeces and urine), household wastewater and rubbish at an affordable rate in a sustainable manner. The MDG for sanitation is to halve, by 2015 , the proportion of people who have no access to basic sanitation. The estimated funding requirements range from US\$ 2.1 to 23 billion and going beyond the more basic definitions of urban service provision will cost again more. Already Camdesus report in 2003 (Winpenny, 2005) had suggested an additional US\$ 32 billion a year and if a broader definition including treatment of all municipal and industrial wastewater and solid waste would be used US\$ 100 billion a year would be necessary. An overview of the progress with household sanitation in South Asia is provided by Sijbesma (2008).

We will deal mainly with the disposal of human excreta (improved sanitation) and leave out what is sometimes included in the wider definition of sanitation (see Table 1). The Global Water Initiative (GWI) concludes in its March 2005 issue (www.global waterintel.com) that to date limited progress has been made towards the achievement of financing these MDGs. Only the Eastern Asian countries are ahead of the targets set in 2000, while Sub-Saharan Africa is falling far behind. ${ }^{4}$ 
Table 1 Different definitions of sanitation

\begin{tabular}{llll}
\hline $\begin{array}{l}\text { Elements of } \\
\text { sanitation }\end{array}$ & Proposed solutions & $\begin{array}{l}\text { Covered by } \\
\text { Johannesburg plan of } \\
\text { implementation }\end{array}$ & $\begin{array}{l}\text { Covered by Joint } \\
\text { Monitoring } \\
\text { Programme of } \\
\text { UNICEF-WHO }\end{array}$ \\
\hline Human excreta & $\begin{array}{l}\text { Provide access to } \\
\text { toilets }\end{array}$ & Yes & $\begin{array}{l}\text { Called improved } \\
\text { sanitation }\end{array}$ \\
$\begin{array}{l}\text { Household } \\
\text { wastewater }\end{array}$ & $\begin{array}{l}\text { Remove used water } \\
\text { from within } \\
\text { households }\end{array}$ & $\begin{array}{l}\text { Yes, together with } \\
\text { human excreta called } \\
\text { basic sanitation }\end{array}$ & No \\
$\begin{array}{l}\text { Storm water } \\
\begin{array}{l}\text { Other sewage } \\
\text { effluents to be } \\
\text { treated }\end{array}\end{array}$ & $\begin{array}{l}\text { Reclaim used and } \\
\text { dirty water by } \\
\text { removing pollution }\end{array}$ & No & No \\
\hline
\end{tabular}

Lack of clean water and sanitation is the second most important risk factor for people in developing countries, after malnutrition. Problems with public sector supply of water and sanitation services have led to the increasing awareness that more participation of the non-state sector is needed in the provision of these services. The problems have been classified as institutional, technical, social and financial (Asian Development Bank (ADB), 2007). ${ }^{5}$ They explain to a large extent the poor performance of many public authorities (Table 2).

Table 2 Main challenges in the sanitation sector in developing countries

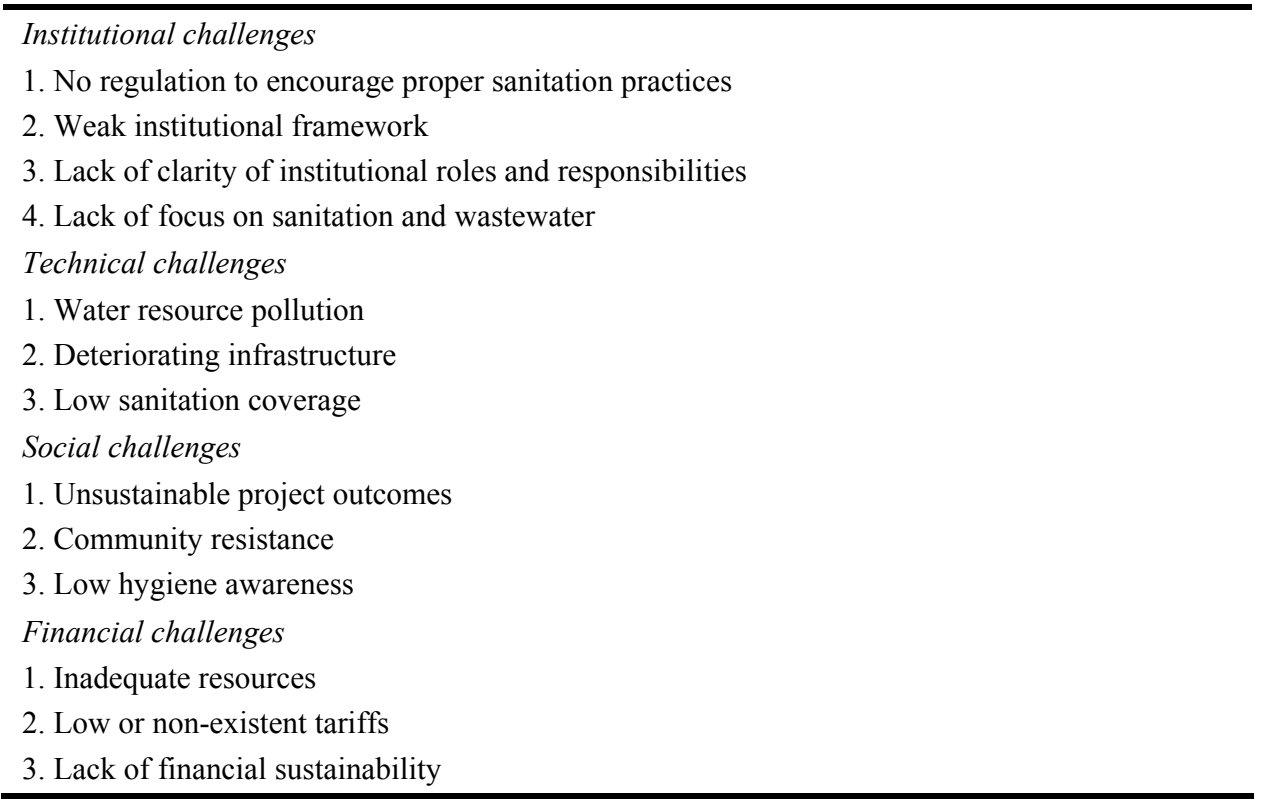

Source: ADB (2007)

Private Sector Involvement (PSI) is frequent in sanitation. It is not really a public good, since people can (and are) be excluded and the system is rivalled, meaning if some households use it the capacity may not be enough for everybody. A reason for the government to get involved would be the negative and positive external effects 
(see Table 3). ${ }^{6}$ However, as such positive or negative external effects are not a strong reason to supply the services by the government. In fact the activity can be outsourced and regulated in such a way that these external factors are taken into account. In case of important externalities, there is the need to assure investments in the sector, over and above what private operators are doing because the socioeconomic benefits are larger than the financial benefits resulting from a private cost benefit analysis. Externalities may lead to formulating clear aims for sanitary systems, such as being attractive and hygienic. The challenge is then to make them also affordable to the population and easy to maintain.

Table 3 Positive and negative external effects of drinking water and sanitation

\begin{tabular}{lll}
\hline Externality & Water & Sanitation \\
\hline $\begin{array}{l}\text { Positive, if piped systems } \\
\text { producing good quality } \\
\text { are in place }\end{array}$ & $\begin{array}{l}\text { Better health } \\
\text { Hegative, if system is in labour productivity } \\
\text { place }\end{array}$ & $\begin{array}{l}\text { Improved health } \\
\text { More dignity and security }\end{array}$ \\
$\begin{array}{lll}\text { Negative, if not in place } \\
\text { Chemicals in the environment }\end{array}$ & $\begin{array}{l}\text { Such services require space and } \\
\text { may smell }\end{array}$ \\
& $\begin{array}{l}\text { Much time lost, often by } \\
\text { women }\end{array}$ & $\begin{array}{l}\text { Diseases can spread easily } \\
\text { No dignity and security problems } \\
\text { for women }\end{array}$ \\
\hline
\end{tabular}

There are many examples of PSI in sanitation. In Indonesia Public-Private Partnerships (PPPs) in this sector started, for example in the 1990s. The Indonesian president even promulgated a presidential decree to promote them (No. 7/1998) and the ADB (2004) provides technical assistance and loans for this purpose. China has a number of Build Operate and Transfer (BOT) contracts in the water and sanitation sector, many with local companies or investors, because this is a municipal responsibility (Tu Shan, 2006). In the case of wastewater treatment the Ministry of Construction has the lead and usually also manages to mobilise the partners and the necessary finance, also form the private sector.

However, even in China even large cities like Chengdu (10.6 million inhabitants) have only about $80 \%$ of the centre of town served by a piped centralised sewer system. On top of that, only $60 \%$ of the sewage produced finds its way through the system, because not all buildings are connected. Typically the situation in the periphery of Chengdu is the opposite. There only $20 \%$ of the area benefits from a networked sewerage system, while the other inhabitants and businesses have to find private solutions.

Sometimes water and sanitation activities are taken up together in PSI projects. However, the drinking water component usually receives much more publicity (as was the case for the Buenos Aires concession, for example). In other cases there is a management contract for sanitation, which does not draw as much attention as a concession contract for drinking water, because people do not really know who takes care of the wastewater and the contract period tends to be shorter. For example, the French water company Suez runs a number of wastewater systems in the USA (Mathew, 2003). The relative good performance of these systems is rarely mentioned in the critical discussions about the role of the private sector in water and sanitation.

Big international water companies are mainly interested in running large-scale centralised waste water treatment systems, if they are combined with drinking water (making charging the consumer easier), if they do not have to invest themselves (they do not consider themselves to be the bankers of the water sector any more) or if there is a 
possibility to recover the investments in another way (e.g. a municipality pays for every litre of treated water). Attention has shifted however from the big centralised systems to the potential of decentralised systems combined with small-scale sanitary improvements. The latter allow people, enterprises or neighbourhoods to take the initiative or participate in it. This change is a kind of a paradigm shift in sanitation. ${ }^{7}$

The different options in the water and sanitation sector are illustrated by giving examples in Table 4. PSI in sanitation has a double meaning. It means on the one hand that individual households need to find a solution for their sanitary problems. On the other hand, the households may involve private firms for the construction or maintenance of the facilities. In Table 4 we distinguish private versus public and on-site versus off-site solutions. In the latter case these would be collective or community solutions (WSP, 1998).

Table 4 Private versus public on-site and collective solutions

\begin{tabular}{llll}
\hline & Arrangement & Water & Sanitation \\
\hline Solutions on-site & Public & Piped connection & Sewerage network \\
& Private & Well or bore hole & Not connected pit \\
& & Home delivery & latrine or septic tank \\
Off-site solutions & Public & Standpipes & Community toilets \\
& & Public wells & \\
& Private & Uncontrolled sources & \\
& & Autonomous water kiosks & Private paying toilets \\
& & Uncontrolled \\
\hline
\end{tabular}

For different reasons (see Box 1) large-scale network sewerage solutions are too expensive to introduce on a large scale in developing countries. To achieve the relevant MDG a different approach will have to be taken. ${ }^{8}$ Since in a number of countries there is no separate institutional structure in place to manage sewerage systems, it is often left to the drinking water companies to take care of this issue. ${ }^{9}$ In fact if the water companies can put a surcharge for sewerage on the water fee, then their financing problem will be partly solved. Otherwise we may have to rely more on SSIPs in the case of sanitation.

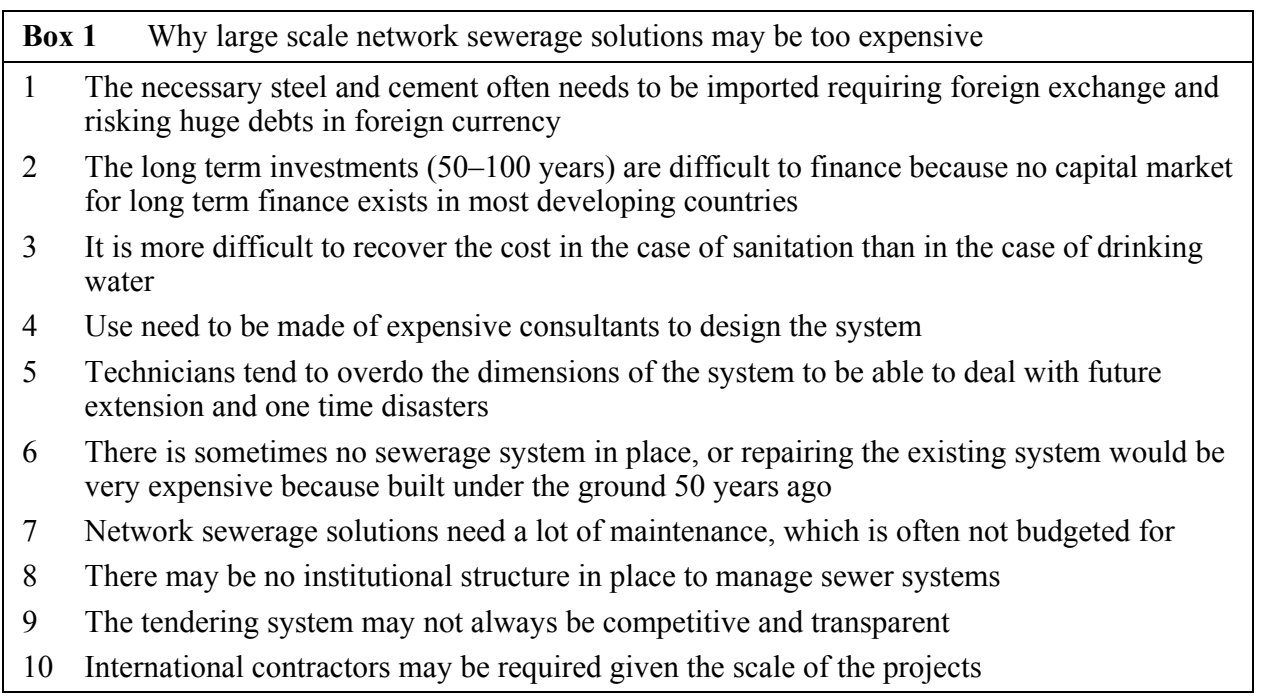




\section{Competition is easier in sanitation than in drinking water}

Liberalisation is a process by which competition is introduced in situations or sectors hitherto characterised by exclusive or special rights, or monopoly, granted to historical operators. We will argue that more competition is possible in sanitation and related activities more so than in the drinking water sector. Private solutions and PSI are more likely because there are no economies of scale, such as the ones existing in drinking water systems. Secondly, drinking water supply is more often characterised as a natural monopoly in the distribution system, which is not the case in sanitation, where there is a real dual system since sometimes $85-90 \%$ of the urban population in developing countries depends on private solutions. The natural monopoly in drinking water supply can be overcome with common carriage and inset arrangements, which can create real competition and exists in several European countries (van Dijk, 2003). In practice common carriage and inset arrangements make up only between 5 and $10 \%$ of the drinking water in countries like The Netherlands, and England and Wales. Through inset arrangements the regional monopoly can be broken. Even if currently its use is limited, the possibility to compete already limits monopolistic behaviour. The taste and quality of the water may be different in the case of sharing arrangements, and the responsibility for negative health consequences may become more diffuse in the case of inset arrangements. In drinking water it is not as easy as in, for example the power sector to break natural monopolies by linking different networks.

In sanitation one finds competition. The sanitation and drinking water sector in developing countries can be described as a dual system if $85-90 \%$ of the people in developing countries depend on private sanitary solutions and $65 \%$ on private water suppliers as is the case in urban Benin. Private water vendors play an important role in supplying at the average $20 \%$ or more of the urban population in developing countries (World Bank, 1988). This implies that the role of the private sector is much more important than generally admitted. It competes with the relevant public utilities. The major mechanisms to achieve more efficiency in service delivery are the possibility of unbundling, technological progress and more competition. The factors influencing the choice of an appropriate sanitation solution are depicted in Figure 1 and will be discussed, after dealing with the experiences with SSIP first.

\section{Experiences with small-scale individual providers}

To what extent do small-scale private individual providers or operators (i.e. SSIP) provide basic infrastructure services in developing countries (Collignon and Vezina, 2000)? Although there are usually economies of scale in networked systems, small-scale operators are tremendously important. The data presented in Table 5 concern the role of SSIP in water services. The origin of the data is described in Box 2.

Box 2 Data on small-scale private operators in water and sanitation

The World Bank undertook a literature review of small-scale private operators of water supply and sanitation (Kariuki and Schwartz, 2005), defining small as less than 50,000 customers. The database (over 400 documents) is available under 222.rru.worldbank.org. The 400 documents reviewed provided evidence for about 50 countries and 100 different locations in these countries. In total some 10,000 water SSIPs were identified, which maybe still only part of the total, given there are more countries and the SSIPs sometimes are informal or illegal. Table 5 summarises the findings. 
Figure 1 Elements of an appropriate sanitation solution

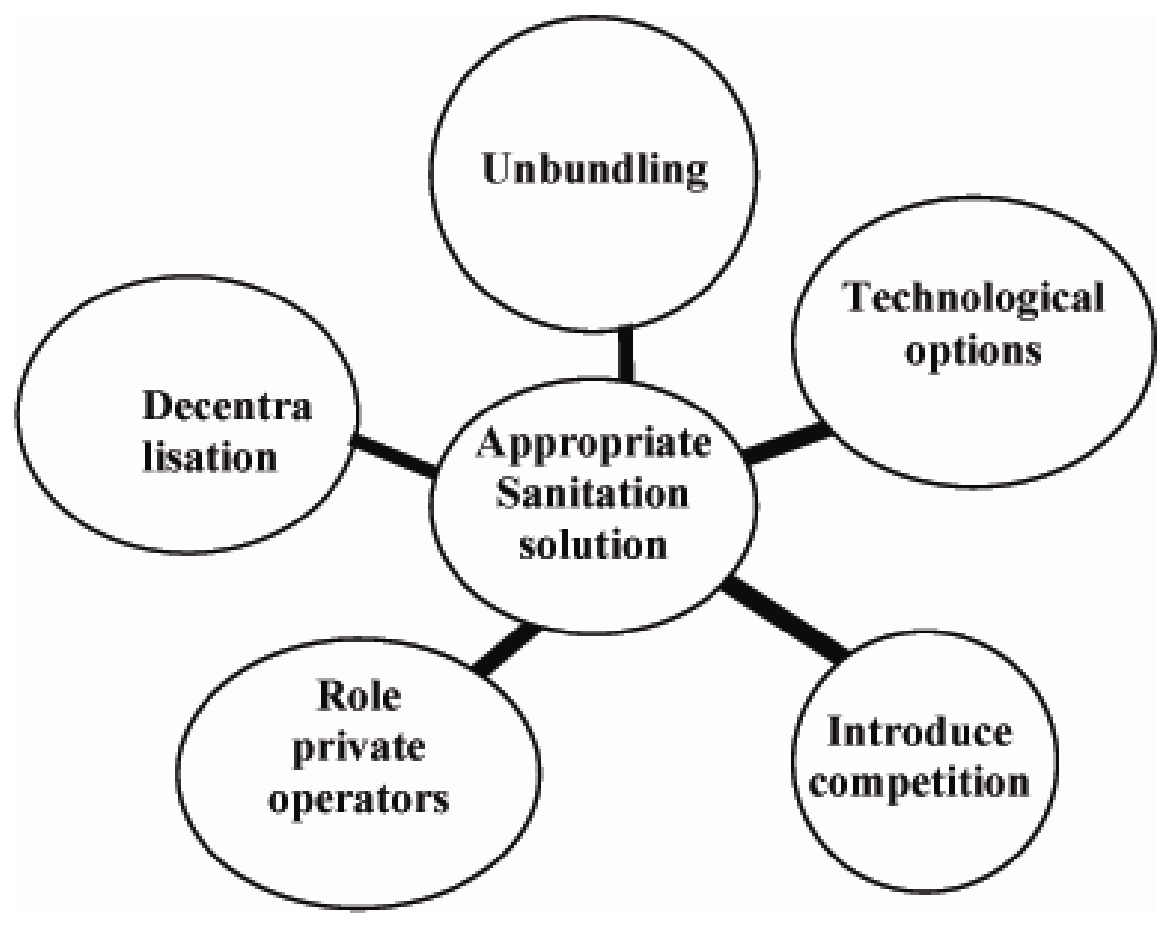

Both formal and informal operators are considered, given that they are difficult to distinguish. An estimate is provided of the number of people receiving their services from SSIP and it is indicated in which regions this is most common. In both the drinking water and sanitation sector there are in fact dual systems and there are reasons to build upon that reality, providing more space to the private providers and individual households.

Only $10-15 \%$ of the urban population in developing countries benefits from access to a sewer network according to WUP (2003). The rest depends on on-site or collective facilities. In case small-scale sanitation solutions are adopted, there does not have to be a private operator except may be in the construction phase, given the role of the community. When the alternative for a sewerage system is a septic tank or a closed pit latrine, the question of emptying those arises. This may be the responsibility of the household, of a private service provider, or a public operator. Unfortunately no detailed figures for SSIP in sanitation are provided by Kariuki and Schwartz (2005). Table 5 provides data for 33 cities concerning water SSIP. Per city the percentage of households being served by the SSIP is given.

What strikes is the huge variation between and even within countries. In Senegal, for example only $21 \%$ of the households in the capital Dakar are served by SSIP, while in Diourbel, a city more in the interior, it goes up to $90 \%$ ! It usually varies between 0 and $30 \%$. 
Table 5 As $\%$ of the total data for 33 cities concerning water SSIP

\begin{tabular}{|c|c|c|}
\hline Region and countries & Water SSIPs in city & $\begin{array}{l}\text { Households served by SSIP in } \\
\text { percentage }\end{array}$ \\
\hline \multicolumn{3}{|l|}{ Africa } \\
\hline Benin & Cotonou & 69 \\
\hline \multirow[t]{2}{*}{ Burkina Faso } & Ouagadougou & 49 \\
\hline & Niangolo & 68 \\
\hline \multirow[t]{2}{*}{ Ivory Coast } & Abidjan & 35 \\
\hline & Boundiali & 50 \\
\hline Ghana & Kumasi & 32 \\
\hline Guinea & Conakry & 66 \\
\hline Kenya & Nairobi & 60 \\
\hline Mali & Bamako & 63 \\
\hline Mauritania & Nouakchott & 51 \\
\hline Niger & Guidan & 40 \\
\hline \multirow[t]{2}{*}{ Nigeria } & Onitsha & 95 \\
\hline & Ibi & 40 \\
\hline \multirow[t]{2}{*}{ Senegal } & Dakar & 21 \\
\hline & Diourbel & 90 \\
\hline Sudan & Khartoum & 80 \\
\hline Somalia & Ali Matan & 10 \\
\hline Tanzania & Dares Salaam & 56 \\
\hline Uganda & Kampala & 30 \\
\hline \multicolumn{3}{|c|}{ Latin America \& Caribbean } \\
\hline Argentina & Cordoba & $15-20$ \\
\hline Bolivia & Santa Cruz & 100 \\
\hline Colombia & Barranquilla & $20-25$ \\
\hline Guatemala & Guatemala & 32 \\
\hline Haiti & Portau-Prince & 70 \\
\hline Honduras & Tegucigalpa & 30 \\
\hline Paraguay & Asuncion & 30 \\
\hline Peru & Lima & $26-30$ \\
\hline \multicolumn{3}{|l|}{ East Asia and Pacific } \\
\hline Cambodia & Ky Cham & 50 \\
\hline Indonesia & Jakarta & 44 \\
\hline Philippines & Manilla & 30 \\
\hline Thailand & Sawee & 10 \\
\hline Vietnam & Ho Chi Minh & 19 \\
\hline \multicolumn{3}{|l|}{ South Asia } \\
\hline Mongolia & Ulaanbaatar & 5 \\
\hline Nepal & Kathmandu & $5-7$ \\
\hline Pakistan & Karachi & $40-50$ \\
\hline India & Delhi & $6-47$ \\
\hline Bangladesh & Dhaka & 14 \\
\hline
\end{tabular}

Source: Kariuki and Schwartz (2005) 
The role of SSIP in the water sector is most wide spread in Africa, while for South Asia SSIP are most prevalent in areas with low coverage levels and ineffective public utilities, in particular in India and Pakistan. Also they are important in remote areas. Kariuki and Schwartz (2005) have analysed the features of these SSIP and classify them according to organisational form (cooperatives to private ventures), technology, staffing (usually less than ten employees), customer service and marketing, financing and pricing, sales and earnings. These activities tend to be outside the legal framework and production is usually at a very small-scale. However, a high proportion of local and often unskilled labour is involved and there are very low levels of initial investments. The conclusion is that SSIP are very diverse and often threatened by an extension if the coverage of the formal supply network is extended. The challenge is to consider SSIP as complementary and incorporate informality when formal supply of urban services in not adequate (van Dijk, 2006). Part of the solution of the MDGs may come from these other providers.

Poor people often pay a high price per litre because SSIP do not have access to subsidies and SSIP are unable to benefit from economies of scale. Nor can they assure the quality of their water. Externalities will often not be taken into consideration by a private operator and hence the price is not reflecting the real cost. Price differences with the publicly supplied water range from 1.5 to 2.5 times the official public utility price, and may increase in times of scarcity. However, the key advantage of SSIP is that they deliver the water at home. More research on this topic may be desirable. ${ }^{10}$

Moreover, WUP (2003, p.53) considers that intermediate and independent service providers are filling the gap between the public suppliers and no supply. They suggest working with the local sub-network providers and water carriers and tankers to improve services. The small-scale providers have the potential to become local small-scale private operators in small towns. Over time they can play a more important role in medium and large towns.

There are strong reasons to try to increase the role of the private sector operators as a percentage of a total turnover in the water and sanitation sector and to encourage their development. The government could impose a specific status for these operators in the water and sanitation sector, giving them, for example fiscal incentives and asking a certain quality of water in return. For quality and environmental reasons some governments may not want to promote small-scale private operators and on-site solutions in drinking water. However, given the size of the sanitation problem and the ambitious MDG in this respect, given the difficulty to recover the cost of sanitation and the huge amounts that need to be invested for on-site public solutions involving a network and centralised wastewater treatment, governments may be inclined to promote the existing on-site private sanitation solutions, in which case they could provide more space to SSIP in the water and sanitation sector.

If drinking water resale initiatives and private sanitation solutions are encouraged it is important to raise the public awareness of health and hygiene issues and to clarify the respective roles of public and private players in the water and sanitation market. The Organisation for Economic Co-operation and Development (OECD) global forum on sustainable development also concluded that policies are necessary to enable the private sector to play a greater role in helping to achieve the MDGs. ${ }^{11}$ 


\section{Efficiency through unbundling, technological developments and competition}

Increased efficiency in sanitation can be achieved through involving the private sector, which through a combination of unbundling, technological developments and more competition can bring about lower tariffs. In other utility or network sectors these are the factors contributing to lower cost of service provision. For example, all three factors have contributed to lower prices in the telecommunication and electricity supply sector and technological progress may currently change the drinking water sector, when desalination is really becoming competitive. The importance of these options in the sanitation sector will now be discussed.

\subsection{Unbundling}

Increased efficiency in the utility sector is often a combination of unbundling, technological development and more competition (van Dijk, 2003). All this is happening in the sanitation sector and makes the involvement of private sector operators more likely and more effective. They can be involved in small-scale construction, the maintenance and emptying of the sanitary facilities. Unbundling in the sanitation sector is depicted in Figure 2. The three different stages in the case of sanitation that can be distinguished and should be separated are (also Figure 2) as follows:

1 building toilets (different technologies, see Table 6), going for individual or collective solutions

2 operation and maintenance can be outsourced and emptying and transport can be done by small private operators

3 recycling can be done by separate actors, preferably also local enterprises.

Figure 2 Three levels for unbundling in sanitation allowing PSI

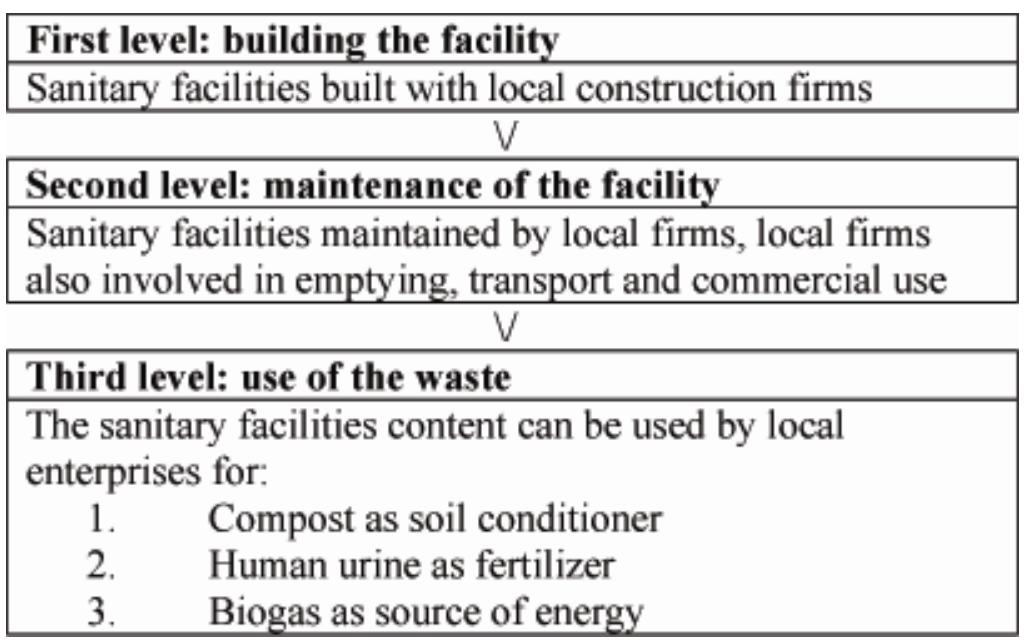

Figure 2 shows that at each level different operators can be effective and encouraged. 


\subsection{Technological progress}

For sanitation, just like in the drinking water sector one can have at least ten technological options to solve supply problems. For the drinking water sector this may be better known. Besides house connections and yard taps we refer to different delivery modes (water vendors or public tanker trucks), wells (communal open or tube wells), tanks (in the yard or on the roof) and solutions outside the plot (water kiosks or communal standpipes). Each option has certain advantages and disadvantages and commands a price.

There are many different types of toilets. In the following Table 6 we try to list criteria for the classification of these toilets, without being exhaustive. To keep it simple we do not mention the management structure, the cost recovery approach or the scale of the facility.

Table 6 Different criteria to classify technologies in drinking water and sanitation

\begin{tabular}{|c|c|c|}
\hline Criteria & Drinking water & Sanitation \\
\hline Connected to piped system & $\begin{array}{l}\text { Individual drinking water } \\
\text { connection }\end{array}$ & Individual sewer connection \\
\hline Individual or collective & On-site or off-site solution & On-site or off-site solution \\
\hline Dry or using water & No pressure, no ground water & $\begin{array}{l}\text { Flushing, pour or dry toilet, } \\
\text { using chemicals, charcoal or } \\
\text { nothing. Also, water-less } \\
\text { urinals to separate urine }\end{array}$ \\
\hline Urine diversion or not & Does not apply & Sophisticated solution \\
\hline Simple or improved & Well or borehole & $\begin{array}{l}\text { Bucket, pit latrine } \\
\text { (often inadequate) versus } \\
\text { basic VIP latrines }\end{array}$ \\
\hline Storage & Yes or no tanks & Septic tank or using drains \\
\hline
\end{tabular}

Then we distinguish seven types of toilets, but there are of course combinations of the different types listed and the varieties mentioned in the table, like a dry urine diversion toilet. The bottom line is that there is enough scope for unbundling and competition and we have to find the optimal solution for a specific situation.

In sanitation we can distinguish:

1 ordinary or unimproved pit latrines, which is basically a pit with a seat in a shelter. They can be constructed by the people but may be poorly built and have problems with flies and stench

2 bucket sanitation systems have the same problems and the buckets may fill rapidly

3 VIP or ventilated pit latrines, where the pit has a reinforced concrete cover, where the air can circulate, while anti-mosquito screens keep out the flies. A high groundwater table would cause problems, just like a rocky soil

4 aqua-privy with on-site disposal or simplified network to evacuate the liquid effluent which otherwise needs to soak away. The digester requires periodic emptying and some water is needed for flushing

5 septic tank is similar to the aqua-privy with on-site disposal, but uses a full-flush system. The system is expensive and requires emptying and sludge disposal 
6 intermediate (using less water) and full-flush toilets where all waste goes to a sewer. These are expensive systems to construct, using a lot of water

7 eco-sanitation, for example composting and composting/urine diversion toilets.

\subsection{Competition}

Competition is possible since in fact a dual system exists in the sanitation sector and different technologies are available. One finds at the same time on-site sanitation and large-scale centralised waste water treatment plants and hence there is competition. On-site sanitation happens in the periphery of the big cities. The technologies range from pit latrines to recycling grey water in each important urban project in the case of Beijing. This is done since piped sewerage system linked to wastewater treatment plants are very costly. ${ }^{12}$

Owing to the unbundling and the technological progress, more competition is possible leading normally to lower prices for the customers. Besides the natural monopoly argument it is often said that water and sanitation are public goods, if only because of the negative external effects. Certainly a number of positive and negative external effects of drinking water and sanitation can be mentioned. They differ for a chemical toilet or a pit latrine and vary from an open soak away pit to a septic tank. These external effects need to be taken into consideration when considering the choice of a technology.

\section{Finance sanitation services}

We noted that large-scale sanitation activities are difficult to finance, given the large amounts needed and the lack of cost recovery mechanisms. The private sector can get in if the projects are really conceived as economic investments with a return. This requires an emphasis on ways and means to finance sanitation services and recover the cost. Cost recovery is possible through the following:

1 contributions from the people benefiting from the system, possibly in kind

2 linking sanitation to drinking water

3 charging connection fees

4 asking small contributions to the necessary investments

5 using private construction firms, and local small enterprises for building, Operation and Maintenance (O\&M) and for emptying and finally small enterprises for recycling the liquid waste products.

Many alternative financial solutions have been suggested, ranging from cross-subsidies to using micro-loans to pay for connection fees (Winpenny, 2005). The bottom line is that some subsidy can be provided (e.g. cross-subsidies for the poor) and the first 200 litres drinking water per household per day can be provided for free (the life-line approach), but if there is no money in the system, it will run dry. 


\section{Conclusions}

Private sector involvement can make a contribution to the achievement of the MDGs, given the financial and skill bottlenecks for the fulfilment of the MDGs in the water and sanitation sector in Africa, Latin America and Asia. There are some dilemmas concerning the role of the private sector in relation to the achieving the MDGs. The role of the private sector can never be to take over the political responsibility of the government. They can also not take the decision to go for large-scale centralised or for decentralised wastewater treatment. Once decisions like what will be solved collectively and what will be left to individuals are taken, the private sector can execute the activities required and will probably become more efficient than the government in supplying these services.

Realistic prices for such services and involving the private sector where and when adequate is important. One way to achieve satisfactory results is to follow the methods suggested by the European Union Water Initiative (EUWI). It is suggested to involve as many parties as possible in the construction, operation and financing of the required facilities and to bring them together before actually starting to identify possible bottlenecks.

The need for alternative technologies should be underlined. A fully fledged sewerage system in every African city would contribute to an even higher debt in foreign currency in many African country, given the steel and cement to be imported. Finally, capacity building is extremely important, to allow local organisations and local firms to carry out most of the work and to assure the necessary investments will have a maximum effect on the local economy and that they will also be maintained locally.

Increasing access to safe water and sanitation in peri-urban areas of large cities requires (a) increasing the efficiency of urban water supply systems and water demand management, and (b) developing and implementing new sustainable forms of sanitation, including eco-sanitation technologies. Although facilities for collection, treatment and disposal of waterborne sewage also exhibit significant scale economies, it is worth considering when decentralised systems and small-scale private sector providers can be used more. They usually involve other private actors and private capital, although sometimes the large-scale government owned waste water treatment plants also attract private funding and management. ${ }^{13}$

\section{References}

ADB (2004) Small Piped Water Networks: Helping Local Entrepreneurs to Invest, Asian Development Bank, Manila.

ADB (2007) Smarter Sanitation: How to Clean up Your Sanitation and Waste Water Mess, Asian Development Bank, Manila.

Collignon, B. and Vezina, M. (2000) Independent Water and Sanitation Providers in African Cities, Water and Sanitation Program, Full Report of a Ten-Country Study, Washington.

Kariuki, M. and Schwartz J. (2005) Small-Scale Private Service Providers of Water Supply and Electricity, World Bank, Washington.

Mathew, N.B. (2003) Performance Analysis of Privately and Publicly Managed Waste Water Utilities in Indiana and Surrounding States, MSc Thesis, UNESCO-IHE Institute for Water Education, Delft. 
Sijbesma, C. (2008) 'Sanitation and hygiene in South Asia: progress and challenges', Background Paper for the South Asian Sanitation and Hygiene Practitioners Workshop in Dhaka, BRAC, WaterAid and IRC, Dhaka, Bagladesh.

Tu Shan (2006) The Use of BOT Contracts in the Water Sector in the People's Republic of China, MSc Thesis, UNESCO-IHE Institute for Water Education.

van Dijk, M.P. (2003) Liberalization of Drinking Water in Europe and Developing Countries, UNESCO-IHE Institute for Water Education, Delft.

van Dijk, M.P. (2006, December) 'Incorporating informality', Shelter, HSMI, New Delhi, Vol. 9, No. 4, pp.14-21.

van Dijk, M.P. (2007) 'Ecological cities in China, what are we heading for, just more ecological urban water systems?' A Contribution to the Switch Annual Conference, 26-27 November, Tel Aviv, 13 p.

Winpenny, J. (2005) Guaranteeing Development? The Impact of Financial Guarantees, OECD.

World Bank (1988) The Role of Public Finance, World Development Report, World Bank Washington.

WSP (1998) Community water supply and sanitation conference, Proceedings. Nairobi: Water and Sanitation Program.

WSP (2004) Sanitation is a business, Approaches for demand-oriented policies. Nairobi: Water and Sanitation Program.

WUP (2003) Better water and sanitation for the urban poor, Good practice from sub-Saharan Africa. Nairobi: Water Utility Partnership for Capacity Building (WUP) Africa.

\section{Notes}

1 Water and sanitation are linked because contaminated water may result in water borne diseases such as viral hepatitis, typhoid, cholera, dysentery and other diseases that cause diarrhea. Without adequate quantities of water for personal hygiene, also skin and eye infections, particularly trachoma, spread easily. Finally, drinking water can contain high amounts of harmful chemicals, such as arsenic and nitrates, which can lead to diseases.

2 In the Buenos Aires concession a water connection would cost the equivalent of US\$ 500 , while a sanitation connection would cost twice as much.

3 In fact only the detailed distribution network is a monopoly and this problem can be overcome by sharing agreements (van Dijk, 2003).

4 Several programmes are active to help African countries to achieve these MDGs. For example, the Water and Sanitation Program (WSP, based in Nairobi) with support from The Netherlands and other donors has studied in a number of African countries where they are and what still needs to be done (WSP, 2004).

5 One could add operational, commercial, human and environmental problems.

6 Similarly it can be said that water and sanitation may be merit goods, but that does not mean the government has to supply them, but the government could enable their supply in the desired manner through regulation.

7 The EU supported SWITCH project seeks to facilitate a paradigm shift in urban water management, aimed at increasing the sustainability and reducing the risks associated with the urban water cycle. To reach this goal new methodologies (including multi-stakeholder learning alliances) and technologies are developed, and existing ones mobilised, to demonstrate water management with higher socioeconomic and environmental efficiencies (van Dijk, 2007).

8 In the framework of the EUWI efforts have been made to start a dialogue in a number of African countries on how to achieve these MDGs with the involvement of all actors: local governments, Non-Governmental Organisations (NGOs) and the private sector. After organising a dialogue, a road map, or sector plan would have to specify the minimum acceptable level of access to water supply and sanitation. Subsequently a financing strategy is 
developed to indicate how these objectives can be achieved. The objective of such a financing strategy is achieving MDGs through PSI in water and sanitation, or by tapping as many sources of finance as possible.

9 Tunisia is an example of a separate National Sanitation Utility, which seems to work very well.

10 Some of the themes for such research are: which factors explain why there are so many SSIP in certain countries compared to others? Why are certain public or private operators doing better than others? What are the definition and examples of best practices? What are viable policy options for policy reform/develop reform agenda for water and sanitation sector, providing space to private small-scale operators?

11 The meeting was held in Paris in November 2006 under the title 'PPPs in water supply and sanitation: recent trends and new opportunities' (www.oecd.org).

12 The duality in Beijing is emphasised by the obligation to reuse the grey water at the level of major construction projects (e.g. hotels or universities). It allows a comparison of centralised and decentralised water treatment options. We currently study the economics of such centralised versus decentralised systems (van Dijk, 2007).

13 Like, for example a new wastewater plant in Harnas polder in The Netherlands, which is totally financed by private partners. 